Chirurgia (2017) 112: 514-523

No. 5, September - October

Copyright $\odot$ Celsius

http://dx.doi.org/10.21614/chirurgia.112.5.514

\title{
Damage Control Resuscitation
}

\section{Jason M Samuels ${ }^{1}$, Hunter B Moore ${ }^{1}$, Ernest E Moore ${ }^{2}$}

'University of Colorado Denver, USA

${ }^{2}$ Denver Health Medical Center, USA

Corresponding author:

Ernest E Moore, MD

Denver Health Medical Center, USA

E-mail: Ernest.Moore@dhha.org

\section{Rezumat}

\section{Resuscitare cu controlul daunelor}

Chirurgia cu controlul daunelor este o asociere de intervenții chirurgicale temporizate în vederea stopării hemoragiei şi a controlului surselor de infecție, scopul resuscitării fiind acela de restabilire a fiziologiei normale. Convenția privind chirurgia cu controlul daunelor s-a dezvoltat în mare odată cu descoperirea triadei letale formate din hipotermie, acidoză şi coagulopatie, scopul Chirurgiei cu Controlul Daunelor (DCS) fiind acela de a evita formarea acestui "cerc vicios" sau de a-i inversa evolutia. In timp ce hipotermia şi acidoza sunt în general corectate prin resuscitare, coagulopatia rămâne o provocare a DCS, fiind exacerbată de administrarea excesivă de cristaloizi. Acest capitol pune accent pe principiile de resuscitare în cele patru cadre ale îngrijirii traumatice: cadrul prespitalicesc, departamentul de urgență, sala de operație şi unitatea de terapie intensivă, incluzând perspective istorice, metode de resuscitare, controverse şi directii viitoare. Fiecare cadru este asociat cu provocări specifice care determină obiective de îngrijire specifice.

Cuvinte cheie: resuscitare, transfuzii, plasmă, sânge, sânge integral, toracotomie, REBOA

\section{Abstract}

Damage control surgery is a combination of temporizing surgical interventions to arrest hemorrhage and control infectious source, with goal directed resuscitation to restore normal physiology. The 
convention of damage control surgery largely arose following the discovery of the lethal triad of hypothermia, acidosis, and coagulopathy, with the goal of Damage Control Surgery (DCS) is to avoid the initiation of this "bloody vicious cycle" or to reverse its progression. While hypothermia and acidosis are generally corrected with resuscitation, coagulopathy remains a challenging aspect of DCS, and is exacerbated by excessive crystalloid administration. This chapter focuses on resuscitative principles in the four settings of trauma care: the prehospital setting, emergency department, operating room, and intensive care unit including historical perspectives, resuscitative methods, controversies, and future directions. Each setting provides unique challenges with specific goals of care.

Key words: resuscitation, transfusions, plasma, blood, whole blood, thoracotomy, REBOA

\section{History of Coagulation in Damage Control Surgery}

In 1906, George Crile, known for his advancements in surgery, successfully completed the first blood transfusion between two humans in the United States (1). A decade later, Walter Cannon proposed the benefits of fluid administration following combat wounds $(2,3)$. By the late 1930s, with lessons learned from World War I along with advances in blood typing and agglutination, European nations began developing blood banking services, providing the ability to store donated blood for up to three weeks (4). For the first time, the developed world could provide both blood and balanced salt solutions for patients following a variety of injuries. However, surgeons relied on limited anecdotal data to guide resuscitation in the hemorrhaging patient.

As the U.S. prepared for the possibility of war in 1940, military leaders realized whole blood would be difficult to provide to combat troops overseas. Edwin Cohen, a biochemist, solved this problem by developing the ability to separate blood into the red blood cell and plasma components (5). Medical personnel in the European and Asian theaters, therefore, had ready access to plasma in treating hemorrhagic shock.

However, not long after, military physicians began noticing the consequences of these strategies. In the $1950 \mathrm{~s}$, researchers uncovered a common sequela of resuscitative strate- gies used in World War II and coined the new syndrome post-traumatic renal failure, suggesting this was related to under-resuscitation (6). This inspired the work of Shires et al who emphasized the role of balanced salt solutions, whichbecame the predominate resuscitative strategies for decades $(7,8)$. The balanced solution strategy was not without consequence of it's own. During the Korean War, signs of traumatic induced coagulopathy (TIC) were observedwith prolonged PT (9).

Subsequently, beginning with the proposal of the bloody vicious cycle by the Denver Health groupin 1982, the concept of damage control resuscitation slowly evolved (10). The following year, Stone et al introduced the concept of damage control surgery in a case series that suggested improved survival with an abbreviated surgical approach to severely injured trauma patients (11). Collectively, the lethal triad became the foundation for damage control approaches to severely injured trauma patients.

\section{Pathophysiology of Trauma Induced Coagulopathy}

Trauma induced coagulopathy (TIC) is a combination of impaired clot formation and rapid clot dissolution. Several mechanisms contribute to this process, and unlike previous clot formation theories that had obvious initiation and termination points such as the classic coagulation cascade theory, in reality, coagulopathy is a 
result of an aberrant homeostasis between a multitude of mechanisms. Understanding these processes is essential for clinicians to accurately intervene, and only recently, with advancements in the measurement of clotting abilities with viscoelastic studies, have such interventions become possible.

Much of TIC is a result of excessive activation of intrinsic anticoagulant functions. One such anticoagulant is activated protein $\mathrm{C}$ (APC). Protein $\mathrm{C}$ is found circulating in plasma, and in response to hypotension and injury, undergoes activationby the binding of thrombin and thrombomodulin forming a complex on the endothelium (12). Once activated, APC cleaves factors Va and VIIIa leading toreduced thrombin generation(13-15).Under normal circumstances, this mechanism serves to maintain vascular patency by preventing thrombosis development. However, this mechanism appears to be upregulated in the setting of hypoperfusion and injury in an attempt to decrease the deleterious effects of cellular dysfunction contributing to the coagulopathy following trauma (12).

The dysregulation of anticoagulant compounds are not the only contributor to TIC. Recent studies have found the vascular endothelium is asignificant contributor to the activation of these pathways. Specifically, the endothelium glycocalyx, with anticoagulant properties due to heparan sulfate, can be shed to varying degrees following trauma, and despite disruption of the endothelium-glycocalyx interaction, shed glycocalyx maintains its heparin-like anticoagulant properties $(16,17)$. This results in systemic endogenous heparinization that contributes to TIC $(18,19)$. Johansson et al observed this mechanism in trauma patients by demonstrating a reversible prolonged clotting time when heparinase was included in thrombelastography samples (20).

Although previously believed to be the primary drivers of TIC, hypothermia, acidosis, and hemodilution are now considered secondary mechanisms.Specifically, hypothermia appears to inhibit the initiation of thrombin generation and impairs fibrinogen synthesis (21). More importantly, acidosis delays propagation of thrombin generation and accelerates fibrinogen degradation. Frequently in severe trauma, acidosis and hypothermia, along with hypotension, worsen due to ongoing bleeding. This exacerbatesa patient's shock including worsened acidosis and hypothermia, forming the basis of the bloody vicious cycle(10).

\section{Prehospital Setting}

Survival in the severely injured patient relies on the timely administration of an appropriate resuscitation strategy while concomitantly addressing the patient's injuries. This involves control of ongoing bleeding, administration of oxygen supplementation and enhancement of ventilation as needed, and by addressing causes of shock that are rapidly correctable such as a tension pneumothorax or pericardial tamponade.

Permissive hypotension represents an example of how clinical researchhas altered prehospital resuscitative strategies. Historically, hypotension was aggressively treated with crystalloid fluids to normalize blood pressure. As early as 1965, Shafton, Dennis, et al (22) reported an increased risk of bleeding in a canine model with arteriotomy following aggressive resuscitation with crystalloid fluids, and againin the 1990s, a number of studies using animal models and clinical data in trauma centers demonstrated the potential adverse effects of early obtainment of normotension with large volume fluid administration (23). In 1994, Bickell et al (24) published a randomized prospective study comparing immediate to delayed fluid resuscitation in penetrating torso trauma, which found that survival increased with a delayed resuscitation strategy. The group theorized that improved survival was a result of avoidance of the harms of aggressive fluid resuscitation, i.e. disruption of life preserving thrombi or exacerbation of ongoing hemorrhage.A large observational study by Brown et al demonstrated increased mortality in normotensive patients who then received continued fluid resuscitation (25). However, this study also demonstrated improved survival when hypotensive patients received fluid resuscitation.Ultimately, hypoten- 
sive resuscitation remains controversial with limited prospective data in blunt trauma, specifically in the setting of concomitant head trauma, as these patients require a higher systolic goal to maintain cerebral perfusion pressure (26). As such, resuscitative strategies must balance the goal of decreasing the duration of shock with an increased risk of bleeding as blood pressure normalizes.

Several theories exist as to the cause of a potentially increased mortality in large volume crystalloid resuscitative strategies. First, as demonstrated in animal models, increased blood pressure could release clots that have slowed or impeded ongoing hemorrhage (27-30). How do these animal studies translate to clinical practice? Theoretically, if EMS and trauma teams aggressively resuscitate severely injured patientsbefore the patient has received surgical interventions, the resultant increase in systolic blood pressure disrupt sites of hemostasis. Moreover, dilution of clotting factors, most notably fibrinogen, may further decrease clot strength (31). Similar studies have suggested this dilutional effectarises from an increased susceptibility totPa-induced fibrinolysis via dilution of fibrinolytic regulators (32).

With concerns rising with the use of crystalloids, groups have begun considering blood products as the first line treatment or at the very least, to use as a supplement for crystalloid when patients require large volumes resuscitation. The first documented use of prehospital red blood cell (RBC) transfusion occurred in 1985, and since then research has slowly advanced the ability of paramedics to institute damage control resuscitation principles even before the patient arrives to the trauma bay (33). Simply providing blood products in the prehospital setting requires advances in systems management and improvementsto paramedic infrastructure such as air and ground ambulance upgrades.

Nevertheless, several retrospective studies have found that early administration of RBCs led to decreased mortality in severely injured patients (34-36). One study also demonstrated a decreased frequency of TIC in blunt trauma patients who received prehospital RBCsas compared to standard resuscitation methods (36), and the practice of providing prehospital blood, especially in air ambulances, appears to be growing. A recent survey of air trauma services determined that one quarter of programs now provide prehospital blood for patients in transport (37). This was especially prominent in trauma programs serving larger, more rural populations with longer transportation times. Certainly, this practice would align with data suggesting negative consequences with large volume crystalloid administration and potential benefits of early blood product administration in the severely injured trauma patient. However, data supporting the use of packed red blood cell (pRBC) administration in the prehospital setting is limited, of poor quality, and has demonstrated a mixed effect on mortality (38). A damage control scenario in an urban setting would not necessitate prehospital blood transfusions with a brief transportation time, but in a rural trauma service with a prolonged transport, prehospital blood could prove beneficial. High quality data is needed to refute or support this theory, asanemia, although a result of hemorrhagic shock, is not the underlying problem.

In contrast, plasma and other procoagulant resuscitative fluids contribute to hemostasis and have thus become the focus of ongoing research. The Prehospital Air Medical Plasma (PAMPer) Trial is also currently enrolling patients in a randomized controlled trial that will study the use of prehospital plasma. However, the aim of the PAMPer trial differs slightly. The trial aims to explore the effects of prehospital plasma on the coagulation and inflammatory response following significant trauma (39). Data from the PAMPer trial may uncover benefits of prehospital plasma outside of encouraging coagulation, and may lead to broader indications for prehospital plasma. Still, these studies are most likely to demonstrate benefits in patients with injuries occurring in austere environments requiring long transport times.

One alternative to fresh frozen plasma is freeze-dried plasma (FDP). Freeze dried plasma has many advantages in the pre- 
hospital setting including a two-year shelf life, rapid reconstitution, universal blood group compatibility, more consistent factor composition, and most importantly for the prehospital setting, the ability to store at room temperature (40). A dry powder would beeasier for air and ground ambulance services to transport. Although developed and successfully implemented during World War II(4), safety concerns due to hepatitis B led to its disuse over the following decades. With the recent data detailing the benefits of early plasma resuscitation and improvements in blood-borne pathogen reduction, FDP has again become a source of interest.

Additionally, civilian and military efforts across the globe are investigating the use of pharmacologic therapies aimed at inhibiting clot breakdown in severely injured patients, namely tranexamic acid (TXA). Much of the growth of empiric administration of TXA was a result of the CRASH 2 trial. CRASH 2, a prospective, randomized placebo controlled trial, provided TXA to patients using an "uncertainty principle" to identify patients to include in the trial (41). The uncertainty principle relied on doctors to determine which patients did or did not clearly require TXA. Patients in which uncertainty as to the need for TXA existed were randomized to either TXA or a placebo. The study demonstrated a survival benefit in patients receiving TXA as compared to placebo and failed to demonstrate an increased risk of thromboembolic events with TXA use; however, due to the logistics of a multinational randomized control trial, data was limited on injury severity of these patients with no laboratory assessment of shock or coagulation status. Moreover, the study found an increased mortality in patients who received TXA greater than three hours after injury. Many concerns arose regarding the methodology of the study, and many questioned the findings. Specifically, the uncertainty principle representsa significant source of selection bias, i.e. many patients were excluded because the clinical picture demanded the use of TXA.Less than half of patients were hypotensive at the time of inclusion, transfusion rates were equivalent between groups, and few died from hemorrhage.On the other hand, it is possible TXA had a survival benefit secondary to an as of yet identified mechanism separate from coagulopathy.

However, camps against empiric TXA use point to several concerns regarding the practice including fibrinolysis phenotypes, discussed later. Trauma services have thus conducted multiple studies following the publication of the CRASH 2 trial and pointed to several potential risks with widespread empiric use of TXA. In actuality, concerns with empiric antifibrinolytics date back to the 1960s, when Starzl et al determined an increased risk of venous thromboembolism in these patients (42). In a similar manner, subsequent sub-analysis of the CRASH 2 trial uncovered an increase in mortality if TXA was given greater than three hours after injury (43). Two retrospective studies at U.S. trauma centers have failed to demonstrate a reduction in mortality with the use of empiric TXA in severely injured trauma patients $(44,45)$. Controversies thus remain and more clarity as to the benefits of TXA are needed.

Moving forward, point of care (POC) testing could drive prehospital resuscitation. With the use of testing modalities such as thrombelastography (TEG), which will be discussed in more detail later, EMS personnel can identify patients who would benefit from directed therapy such as TXA or plasma. Moreover, studies with greater specificity for shock could identify which patients should be aggressively resuscitated. Multiple studies have demonstrated the accuracy of POC lactate, TEG, and hemoglobin (46). One prospective study examining any patient with prehospital shock demonstrated the prognostic value of prehospital POC lactate(47). POC testing lacks data demonstrating an effect on mortality, and more data is necessary before these studies can be included in a prehospital treatment algorithm.

\section{Emergency Department}

Much of trauma resuscitation in the United 
States has been standardized with the strategies developed by the Advanced Trauma Life Support (ATLS) program.The "ABC" algorithm of airway, breathing, and circulation has become the standard of care in the initial management of the severely injured trauma patient and reflects the previously described focus of the initial management in the prehospital setting. However, when present, isolated threats to life should be addressed first.For instance, the trauma team should rapidly address ongoing hemorrhage. Ventilation and oxygenation should be optimized by oxygen supplementation and invasive ventilator maneuvers if indicated, and correctable signs of shock should be identified such as tamponade or tension pneumothorax.Beyond the initial assessment of the patient, transfusion strategies can differ widely. Most hospitals have adopted massivetransfusion(MTP) protocols $(48,49)$, but variation remains between the ratios of RBCs to FFP administered.

The focus of initial resuscitation is correcting the three aspects of the well-defined "lethal triad" of trauma: hypothermia, acidosis, and coagulopathy (10). While hypothermia is easily corrected in the prehospital setting and trauma bay, acidosis and coagulopathy remain a challenge. Thus, research over the last two decades has largely focused on correcting the acidosis without worsening the coagulopathy. Furthermore, the advent of point of care assessment of the coagulation parameters have allowed for the development of personalized resuscitative strategies aimed at correcting abnormalities at each stage of the coagulation cascade.

The widespread use of MTP represents one way in which trauma programs have attempted to rapidly intervene on the progression of the lethal triad. The Denver Health group, for example, has implemented an MTP that is largely automated in the event of the arrivala trauma activation, the designation for the most severely injured trauma patient. Once the trauma activation page is received, the blood bank delivers a cooler with four units of $\mathrm{O}$ negative RBCs and two units of FFP. A second cooler is available with $4 \mathrm{U}$ RBCs, 2 U FFP, and
$1 \mathrm{U}$ of apheresis platelets. The protocol provides instructions on transfusion ratios for all remaining coolers as well. Once hemorrhage control is obtained, the Denver group then relies on TEG guided resuscitation, which will be described in detail later. Gonzalez et alin 2007, highlighted the effectiveness of these MTP transfusion strategies in their prospective observational single institutional study (50). Over a 51-month period, the Houston group analyzed data of ICU admissionsof severely injured trauma patients. During the study period, the previously developed MTP protocol was continued, which transfused sixunitsRBCs prior to FFP administration and sixunitsRBCs and fourunits RBCs in each subsequent cooler. They observed that although hypothermia and acidosis were corrected in patients either prior or shortly after ICU admission, a large majority of patients (85\%) presented to the ICU with ongoing coagulopathy, as defined as INR $>1.2$. However, the elevated INR does not explain the cause of coagulopathy.

Other studies obtained from the Iraq and Afghanistan combat theaters, in contrast, demonstratedthe benefit of a near 1:1 pRBC to plasma transfusionratio. A study by Borgman et al, in which retrospectivelycompared survivors of patients receiving MTP vs nonsurvivors, found a lower RBC to plasma ratio in those who survived serious hemorrhagic trauma (survivors receiveda median ratio of 1:1.6 vs 1:2.3 with nonsurvivors). Moreover, Borgman and colleagues demonstrated that those who received a lower ratio of RBCs to plasma died sooner than those receiving high ratios. This survival benefit from a near 1:1 $\mathrm{RBC}$ to plasma ratio was suggested in retrospective reviews in civilian level I trauma centers (51) as well; however other studies have questioned this conclusion and found equivalent benefit from 1:2 and other low plasma to pRBC ratio practices (52).

The PROMMTT study, a prospective multiinstitutional cohortstudy, attempted to determinethe benefit in the massively transfused patient (53). This study again suggested improved survival in the first six hours as the ratio of transfused $\mathrm{RBC}$ to plasma approached 
1:1. Interestingly, this benefit was lost following the first twenty-four hours. Following the PROMMTT study, 1:1 and 1:2 resuscitation strategiesgained broader acceptance for the severely injured trauma patient. For example, the United States military adopted a 1:1:1 transfusion strategy until hemorrhage control is obtained (54). Nevertheless, lacking randomized data to support a one to one resuscitative strategy, some doubts remained. In fact, one meta-analysis determined a benefit when protocols provided at least a 1:2 ratio of FFP to RBC, but failed tofind any benefit when the plasma to $\mathrm{pRBC}$ ratio approached one (55).

The timing and frequency at which to administer platelets remains a question as well. The previously mentioned PROMMTT trial found that despite the use of damage control resuscitative techniques with earlier plasma administration as compared to historical crystalloid resuscitative strategies, platelets were commonly delivered in a delayed fashion, with only $72 \%$ of patients receiving platelets by three hours after arrival (53). As a result, platelets are oftentimes administered earlier as part of a trauma centers' MTP. Another observational study found that an increased platelet to $\mathrm{pRBC}$ ratio was associated with a survival advantage (56). The Pragmatic, Randomized, Optimal Platelet, and Plasma Ratios (PROPPR) trial attempted to clarify the benefit of platelets as part of a ratio based resuscitative strategy. The study, which compared a 1:1:1 (pRBC/ plasma/ platelet) ratio to 1:1:2 found no significant survival benefit with the lower ratio at 24 hours(57). As a result, while platelets remain integral to appropriate resuscitation, the available data suggests that platelets should be administered at a less frequent rate as pRBCs and plasma.

The use of point-of-care coagulopathy studies represent an alternativemethod to ratio based resuscitation strategies. Thrombelastography (TEG) originally entered the armamentarium of physicians in Europe in the 1950s, and in the United States, transplant and cardiac surgeons have used TEGs on a regular basis for several decades (58).
Historically, TEG equipment was cumbersome, however with recent technologic improvements in the last decade, TEG has become more common in the management of trauma patients. The traditional measures of coagulation PT/INR and aPTT are time consuming, measure coagulation on patient poor plasma, and represent only the first $5 \%$ of clot formation $(58,59)$. Similarly, other than TEG, no widely available assessment of fibrinolysis exists. Most importantly, a more accurate assessment of coagulation would incorporate the previously discussed cell based model of coagulation.

In contrast, TEG can provide data within minutes, and allows a completed assessment of coagulation including fibrinolysis in 90 minutes. TEG provides actionable data points to transfused specific blood products. For example, in rapid-TEG studies, which uses tissue factor to expedite the clotting process, the activated clotting time (ACT) indicates the speed of the initiation and propagation of the coagulation cascade. If prolonged, this indicates consumption or dilution of clotting factors and warrants administration of FFP. The maximum amplitude (MA) of the TEG tracing correlates with platelet function and, if abnormal, would indicate need for additional transfusion of platelets. A prospective, randomized study by Gonzalez et al compared TEG guided resuscitation to transfusion of plasma and other products based on PT/INR, PTT, platelet count, and D-Dimer (60). This study demonstrated a50\% reduction in mortality with TEG guided resuscitative strategy over conventional labs. Of note, the initial resuscitative strategy used a 1:2 RBC to plasma ratio, with subsequent transfusions dependent upon lab indications. Patients in the TEG group overall received less platelets and plasma during the first two hours of resuscitation. This data supports that there maybe a risk with over utilization of these blood products during early resuscitation. However, larger, multi-institutional studies are needed to confirmthese findings.

Prior to the use of TEG, no widely available study provided a rapid assessment of fibrinoly- 
sis. In the age of point of care coagulation studies using TEG, it has become clear that patients can present with this distinct phenotype (61). In fact, TEG studies have pointed to a concerning non-inconsequential frequency of fibrinolysis shutdown. In a prospective study by the Denver Health group among severely injured trauma patients, nearly two-thirds expressed fibrinolysis shutdown on viscoelastic studies (61). A subsequent larger, multicenter trial confirmed this finding with $46 \%$ of patients found to express a fibrinolysis shutdown phenotype(62). Giving such patients with fibrinolytic shutdown, or even physiologic fibrinolysis, antifibrinolytic agents such as TXA at best is an unnecessary expenditure and at worse harmful and potentially lethal. TXA in these patients may lead to an increase in clinically and radiologically evident VTEs as well as thrombi at the capillary level, potentially contributing to multi-organ failure in the severely injured trauma patient. More data is necessary to determine if TEG could guide the use of antifibrinolytic agents by identifying hyperfibrinolytic patients early in the patient's resuscitation. With the current understanding of the beneficial effects of TXA, the evidence suggests that this medication should be used selectively in hypotensive patients who are actively bleeding. Pre hospital use of TXA remains experimental and should only be conducted in a research setting, and no patients should receive this medication if they are more than three hours out from injury.

\section{Operating Room}

Resuscitation in the operating room involves a coordinated effort by the surgical staff, anesthesiologists, and blood bank. First and foremost, excessive crystalloid resuscitation should be avoidedto prevent the worsening of acidosis and coagulopathy. One single institution retrospective study suggested these potential benefits. When comparing severely injured patients undergoing damage control laparotomy, those patients undergoing product based resuscitation with predetermined ratios as compared to a large volume crystalloid resuscitation demonstrated a lower base deficit, higher $\mathrm{pH}$, less hypothermia, and a lower INR upon arrival to the ICU (63). More importantly, after cohort matching, a survival advantage was noted with a product first resuscitative strategy.

Frequently, massive transfusion protocols are continued until the surgical team has obtained hemorrhage control. However, a more guided resuscitative strategy can begin in the operating room using TEG parameters to correct and remaining coagulopathies while providing fluid resuscitation. Using this approach, FFP for an ACT $\geq 128$ seconds, cryoprecipitate for an angle $\leq 65$, platelets for an $\mathrm{MA} \leq 55 \mathrm{~mm}$, and an LY30 $\geq 5 \%(64)$. TEGs would be repeated serially after the infusion of product to continue to monitor for changes in the patient's coagulation status. The optimal hematocrit remains debated, but the concept of margination (65) supports that a hematocrit of 30 is an ideal target for an actively bleeding patient, which can be liberalized to 21 once hemostasis is achieved.

\section{ICU}

Following operative intervention, resuscitation and shock should be corrected as soon as possible. Lactate can guide further fluid resuscitation needs, and one large retrospective study found failure to clear lactate (i.e. lactate $\geq 2 \mathrm{mmol} / \mathrm{L}$ ) at 24 hours was associated with a seven fold increase in mortality (66). Whether crystalloid, RBCs, or other blood products are used as a resuscitative fluid at this point should depend upon objective laboratory measures such as Hct and TEG studies. For example, if a patient continues to demonstrate fibrinolysis as indicated by the previously mentioned TEG parameters, the intensive care staff should administer cryoprecipitate.

\section{Summary and Future Direction}

Resuscitation of the trauma patient has been the focus of research for over half a century with several historical advancements. Yet, much debate remains over the timing and 
choice of fluids administered in the treatment of the severely injured. Recently, a transition to early administration of blood products has occurred, while longstanding products and laboratory studies such as thrombelastography and whole blood are again gaining attention. Currently, ratio based resuscitation strategies predominate with many massive transfusion protocols implementing at least a 1:2 (pRBC/ plasma) initial transfusion strategy. However, several trauma centers now use guided resuscitation strategies following TEG parameters. These strategies will continue to evolve as more data accumulates, and more centers will likely focus on prehospital administration of product. Finally, personalized medicine will likely include changes in trauma care as more studies that assess coagulation, inflammation, and shock become available.

\section{References}

1. Nathoo N, Lautzenheiser FK, Barnett GH. The first direct human blood transfusion: the forgotten legacy of George W. Crile. Neurosurgery. 2009;64(3 Suppl):ons20-6; discussion ons6-7.

2. Cannon W, Fraser J, Cowell E. The Preventative Treatment of Wound Shock. JAMA. 1918;70:618-21.

3. Cannon WB, Gray H. Factors affecting the coagulation time of blood. JAMA. 1914;34(2):232-42.

4. Kendrick DB. Blood Program in World War II 1964

5. Cohn EJ, Oncley JL, Strong LE, Hughes WL, Armstrong SH. Chemical, clinical, and immunological studies on the products of human plasma fractionation. I. The characterization of the protein fractions of human plasma. The Journal of clinical investigation. 1944;23(4):417-32.

6. Maier RV. Scudder Oration on Trauma. A century of evolution in trauma resuscitation. Journal of the American College of Surgeons. 2014:219(3):335-45

7. McClelland RN, Shires GT, Baxter CR, Coln CD, Carrico J. Balanced salt solution in the treatment of hemorrhagic shock. Studies in dogs. Jama. 1967:199(11):830-4

8. Shires GT, Canizaro PC. Fluid resuscitation in the severely injured. The Surgical clinics of North America. 1973;53(6):1341-66.

9. Scott R, Jr., Crosby WH. The hemostatic response to injury; a study of the Korean battle casualty. Ann Surg. 1955:141(3):347-56.

10. Kashuk JL, Moore EE, Millikan JS, Moore JB. Major abdominal vascular trauma--a unified approach. The Journal of trauma. 1982; 22(8):672-9

11. Stone HH, Strom PR, Mullins RJ. Management of the major coagulopathy with onset during laparotomy. Ann Surg. 1983;197(5):532-5.

12. Brohi K, Cohen MJ, Ganter MT, Matthay MA, Mackersie RC, Pittet JF. Acute traumatic coagulopathy: initiated by hypoperfusion: modulated through the protein C pathway? Ann Surg. 2007;245(5):812-8.

13. Gosselin RC, Marshall C, Dwyre DM, Gresens C, Davis D, Scherer L, et al. Coagulation profile of liquid-state plasma. Transfusion. 2013; 53(3):579-90.

14. Zhang L, Jhingan A, Castellino FJ. Role of individual gammacarboxyglutamic acid residues of activated human protein $\mathrm{C}$ in defining its in vitro anticoagulant activity. Blood. 1992;80(4):942-52.

15. Maegele M, Schochl H, Cohen MJ. An update on the coagulopathy of trauma. Shock (Augusta, Ga). 2014;41 Suppl 1:21-5.

16. Becker BF, Chappell D, Bruegger D, Annecke T, Jacob M. Therapeutic strategies targeting the endothelial glycocalyx: acute deficits, but great potential. Cardiovascular research. 2010;87(2):300-10.

17. Senzolo M, Coppell J, Cholongitas E, Riddell A, Triantos CK, Perry D, et al. The effects of glycosaminoglycans on coagulation: a thromboelastographic study. Blood coagulation \& fibrinolysis : an international journal in haemostasis and thrombosis. 2007:18(3):227-36.

18. Zambruni A, Thalheimer U, Coppell J, Riddell A, Mancuso A, Leandro $G$, et al. Endogenous heparin-like activity detected by anti-Xa assay in infected cirrhotic and non-cirrhotic patients. Scandinavian journal of gastroenterology. 2004;39(9):830-6

19. Agarwal S, Senzolo M, Melikian C, Burroughs A, Mallett SV. The prevalence of a heparin-like effect shown on the thromboelastograph in patients undergoing liver transplantation. Liver transplantation: official publication of the American Association for the Study of Liver Diseases and the International Liver Transplantation Society. 2008; 14(6):855-60

20. Ostrowski SR, Johansson PI. Endothelial glycocalyx degradation induces endogenous heparinization in patients with severe injury and early traumatic coagulopathy. The journal of trauma and acute care surgery. 2012;73(1):60-6.

21. Martini WZ. Coagulopathy by hypothermia and acidosis: mechanisms of thrombin generation and fibrinogen availability. The Journal of trauma. 2009;67(1):202-8; discussion 8-9.

22. Chiu CJ, Shaftan GW, Dennis C. Control of experimental hemorrhage with arfonad. The Journal of trauma. 1965;5:392-7.

23. Brakenridge SC, Phelan HA, Henley SS, Golden RM, Kashner TM, Eastman AE, et al. Early blood product and crystalloid volume resuscitation: risk association with multiple organ dysfunction after severe blunt traumatic injury. The Journal of trauma. 2011;71(2):299-305

24. Bickell WH, Wall MJ, Jr., Pepe PE, Martin RR, Ginger VF, Allen MK, et al. Immediate versus delayed fluid resuscitation for hypotensive patients with penetrating torso injuries. The New England journal of medicine. 1994;331(17):1105-9.

25. Brown JB, Cohen MJ, Minei JP, Maier RV, West MA, Billiar TR, et al. Goal-directed resuscitation in the prehospital setting: a propensityadjusted analysis. The journal of trauma and acute care surgery. 2013;74(5):1207-12; discussion 12-4.

26. Carney N, Totten AM, O'Reilly C, Ullman JS, Hawryluk GW, Bell MJ, et al. Guidelines for the Management of Severe Traumatic Brain Injury, Fourth Edition. Neurosurgery. 2016.

27. Bickell WH, Bruttig SP, Millnamow GA O'Benar J, Wade CE. The detrimental effects of intravenous crystalloid after aortotomy in swine. Surgery. 1991:110(3):529-36.

28. Stern SA, Dronen SC, Birrer P, Wang X. Effect of blood pressure on hemorrhage volume and survival in a near-fatal hemorrhage model incorporating a vascular injury. Annals of emergency medicine. 1993:22(2):155-63.

29. Bruttig SP, O'Benar JD, Wade CE, Dubick MA. Benefit of slow infusion of hypertonic saline/dextran in swine with uncontrolled aortotomy hemorrhage. Shock (Augusta, Ga). 2005;24(1):92-6.

30. Bickell WH, Bruttig SP, Millnamow GA, O'Benar J, Wade CE. Use of hypertonic saline/dextran versus lactated Ringer's solution as a resuscitation fluid after uncontrolled aortic hemorrhage in anesthetized swine. Annals of emergency medicine. 1992;21(9):1077-85.

31. Fenger-Eriksen C, Tonnesen E, Ingerslev J, Sorensen B. Mechanisms of hydroxyethyl starch-induced dilutional coagulopathy. Journal of thrombosis and haemostasis: JTH. 2009;7(7): 1099-105.

32. Moore HB, Moore EE, Gonzalez E, Wiener G, Chapman MP, Dzieciatkowska M, et al. Plasma is the physiologic buffer of tissue plasminogen activator-mediated fibrinolysis: rationale for plasma-first resuscitation after life-threatening hemorrhage. Journal of the American College of Surgeons. 2015;220(5):872-9.

33. Dalton AM. Use of blood transfusions by helicopter emergency medical services: is it safe? Injury. 1993;24(8):509-10.

34. Powell EK, Hinckley WR, Gottula A, Hart KW, Lindsell CJ, McMullan JT. 
Shorter times to packed red blood cell transfusion are associated with decreased risk of death in traumatically injured patients. The journal of trauma and acute care surgery. 2016;81(3):458-62.

35. Brown JB, Sperry JL, Fombona A, Billiar TR, Peitzman AB, Guyette FX. Pre-trauma center red blood cell transfusion is associated with improved early outcomes in air medical trauma patients. Journal of the American College of Surgeons. 2015;220(5):797-808.

36. Brown JB, Cohen MJ, Minei JP, Maier RV, West MA, Billiar TR, et al. Pretrauma center red blood cell transfusion is associated with reduced mortality and coagulopathy in severely injured patients with blunt trauma. Ann Surg. 2015;261(5):997-1005.

37. Karl A, Pham T, Yanosky JD, Lubin J. Variability of Uncrossmatched Blood Use by Helicopter EMS Programs in the United States. Prehospital emergency care: official journal of the National Association of EMS Physicians and the National Association of State EMS Directors. 2016:1-7.

38. Smith IM, James RH, Dretzke J, Midwinter MJ. Prehospital Blood Product Resuscitation for Trauma: A Systematic Review. Shock (Augusta, Ga). 2016;46(1):3-16.

39. Brown JB, Guyette FX, Neal MD, Claridge JA, Daley BJ, Harbrecht BG, et al. Taking the Blood Bank to the Field: The Design and Rationale of the Prehospital Air Medical Plasma (PAMPer) Trial. Prehospital emergency care : official journal of the National Association of EMS Physicians and the National Association of State EMS Directors. 2015;19(3):343-50.

40. Martinaud C, Ausset S, Deshayes AV, Cauet A, Demazeau N, Sailliol A. Use of freeze-dried plasma in French intensive care unit in Afghanistan. The Journal of trauma. 2011;71(6):1761-4; discussion 4-5.

41. Shakur H, Roberts I, Bautista R, Caballero J, Coats T, Dewan Y, et al. Effects of tranexamic acid on death, vascular occlusive events, and blood transfusion in trauma patients with significant haemorrhage (CRASH-2): a randomised, placebo-controlled trial. Lancet (London, England). 2010;376(9734):23-32.

42. Groth CG, Pechet L, Starzl TE. Coagulation During and After Orthotopic Transplantation of the Human Liver. Archives of surgery (Chicago, III : 1960). 1969;98(1):31-4.

43. Napolitano LM, Cohen MJ, Cotton BA, Schreiber MA, Moore EE. Tranexamic acid in trauma: how should we use it? The journal of trauma and acute care surgery. 2013;74(6):1575-86.

44. Harvin JA, Peirce CA, Mims MM, Hudson JA, Podbielski JM, Wade CE, et al. The impact of tranexamic acid on mortality in injured patients with hyperfibrinolysis. The journal of trauma and acute care surgery. 2015;78(5):905-9; discussion 9-11.

45. Valle EJ, Allen CJ, Van Haren RM, Jouria JM, Li H, Livingstone AS, et al. Do all trauma patients benefit from tranexamic acid? The journal of trauma and acute care surgery. 2014;76(6):1373-8.

46. Schott U. Prehospital coagulation monitoring of resuscitation with point-of-care devices. Shock (Augusta, Ga). 2014;41 Suppl 1:26-9.

47. Jansen TC, van Bommel J, Mulder PG, Rommes JH, Schieveld SJ, Bakker J. The prognostic value of blood lactate levels relative to that of vital signs in the pre-hospital setting: a pilot study. Crit Care. 2008; 12(6):R160

48. Malone $\mathrm{DL}$, Hess JR, Fingerhut A. Massive transfusion practices around the globe and a suggestion for a common massive transfusion protocol. The Journal of trauma. 2006;60(6 Suppl):S91-6.

49. Etchill E, Sperry J, Zuckerbraun B, Alarcon L, Brown J, Schuster K, et al. The confusion continues: results from an American Association for the Surgery of Trauma survey on massive transfusion practices among United States trauma centers. Transfusion. 2016;56(10):2478-86.

50. Gonzalez EA, Moore FA, Holcomb JB, Miller CC, Kozar RA, Todd $\mathrm{SR}$, et al. Fresh frozen plasma should be given earlier to patients requiring massive transfusion. The Journal of trauma. 2007; 62(1):112-9.

51. Holcomb JB, Wade CE, Michalek JE, Chisholm GB, Zarzabal LA,
Schreiber MA, et al. Increased plasma and platelet to red blood cell ratios improves outcome in 466 massively transfused civilian trauma patients. Ann Surg. 2008;248(3):447-58.

52. Kashuk JL, Moore EE, Johnson JL, Haenel J, Wilson M, Moore JB, et al. Postinjury life threatening coagulopathy: is $1: 1$ fresh frozen plasma: packed red blood cells the answer? The Journal of trauma. 2008;65(2):261-70; discussion 70-1.

53. Holcomb JB, del Junco DJ, Fox EE, Wade CE, Cohen MJ, Schreiber MA, et al. The prospective, observational, multicenter, major trauma transfusion (PROMMTT) study: comparative effectiveness of a time-varying treatment with competing risks. JAMA surgery. 2013; 148(2): $127-36$

54. Rentas F, Lincoln D, Harding A, Maas P, Giglio J, Fryar R, et al. The Armed Services Blood Program: blood support to combat casualty care 2001 to 2011. The journal of trauma and acute care surgery. 2012;73(6 Suppl 5):S472-8.

55. Bhangu A, Nepogodiev D, Doughty H, Bowley DM. Meta-analysis of plasma to red blood cell ratios and mortality in massive blood transfusions for trauma. Injury. 2013;44(12):1693-9.

56. Holcomb JB, Zarzabal LA, Michalek JE, Kozar RA, Spinella PC, Perkins $J G$, et al. Increased platelet:RBC ratios are associated with improved survival after massive transfusion. The Journal of trauma. 2011;71 (2 Suppl 3):S318-28.

57. Holcomb JB, Tilley BC, Baraniuk S, Fox EE, Wade CE, Podbielski JM, et al. Transfusion of plasma, platelets, and red blood cells in a 1:1:1 vs a 1:1:2 ratio and mortality in patients with severe trauma: the PROPPR randomized clinical trial. Jama. 2015;313(5):471-82.

58. Gonzalez E, Pieracci FM, Moore EE, Kashuk JL. Coagulation abnormalities in the trauma patient: the role of point-of-care thromboelastography. Seminars in thrombosis and hemostasis. 2010;36(7): 723-37.

59. Brummel KE, Paradis SG, Butenas S, Mann KG. Thrombin functions during tissue factor-induced blood coagulation. Blood. 2002;100(1): $148-52$.

60. Gonzalez E, Moore EE, Moore HB, Chapman MP, Chin TL, Ghasabyan A, et al. Goal-directed Hemostatic Resuscitation of Trauma-induced Coagulopathy: A Pragmatic Randomized Clinical Trial Comparing a Viscoelastic Assay to Conventional Coagulation Assays. Ann Surg. 2016;263(6):1051-9

61. Moore HB, Moore EE, Gonzalez E, Chapman MP, Chin TL, Silliman CC, et al. Hyperfibrinolysis, physiologic fibrinolysis, and fibrinolysis shutdown: the spectrum of postinjury fibrinolysis and relevance to antifibrinolytic therapy. J Trauma Acute Care Surg. 2014;77(6):811-7; discussion 7.

62. Moore HB, Moore EE, Liras IN, Gonzalez E, Harvin JA, Holcomb JB, et al. Acute Fibrinolysis Shutdown after Injury Occurs Frequently and Increases Mortality: A Multicenter Evaluation of 2,540 Severely Injured Patients. Journal of the American College of Surgeons. 2016;222(4):347-55

63. Duchesne JC, Kimonis K, Marr AB, Rennie KV, Wahl G, Wells JE, et al. Damage control resuscitation in combination with damage control laparotomy: a survival advantage. The Journal of trauma. 2010; 69(1):46-52.

64. Einersen PM, Moore EE, Chapman MP, Moore HB, Gonzalez E, Silliman $\mathrm{CC}$, et al. Rapid-thrombelastography ( $\mathrm{r}-\mathrm{TEG}$ ) thresholds for goaldirected resuscitation of patients at risk for massive transfusion. The journal of trauma and acute care surgery. 2016.

65. Fitzgibbon S, Spann AP, Qi QM, Shaqfeh ES. In vitro measurement of particle margination in the microchannel flow: effect of varying hematocrit. Biophysical journal. 2015;108(10):2601-8.

66. Dezman ZD, Comer AC, Smith GS, Narayan M, Scalea TM, Hirshon JM. Failure to clear elevated lactate predicts 24-hour mortality in trauma patients. The journal of trauma and acute care surgery. 2015; 79(4):580-5. 